The Turkish Online Journal of Design, Art and Communication - TOJDAC

ISSN: 2146-5193, September 2018 Special Edition, p.1080-1090

\title{
HUMANITARIZATION OF VOCATIONAL TRAINING OF STUDENTS AT HIGH EDUCATION INSTITUTIONS APPLYING UP-TO-DATE POSSIBILITIES OF DISTANCE EDUCATION
}

\author{
Alexey Pavlovich ALBOV \\ Moscow State Tchaikovsky Conservatory, Russia \\ Olga Vadimovna STUKALOVA \\ Institute of Art Education and Cultural Studies of the Russian Academy of Education, Russia
}

\begin{abstract}
The paper analyzes the use of up-to-date technologies in distance learning of university students in the conditions of integration and globalization of education. For the first time, the need for humanitarization in the distance education process is theoretically grounded; the specifics of information and communication technologies in the learning process are revealed; the results of the tested model are shown through the distance education system. The interaction of parties to the educational process was studied; surveys, questionnaires and observation of the learning process using contemporary teaching technologies were conducted; the results were generalized using analytical methods, rank correlation. As a result, conclusions were made about the feasibility and possibility of using up-to-date teaching technologies in the process of education humanitarization, demonstrating the most effective methods and pedagogical techniques, proving the need for expanding distance education for comprehensive constructive interaction, forming and developing the creative abilities of future specialists in the field of culture and art.
\end{abstract}

Keywords: Humanitarization of Education, Distance Education, Creative Abilities of a Student, Pedagogical Techniques, Education, Vocational Training

\section{INTRODUCTION}

At the end of the 20th and beginning of the 21 st century, the influence of information technologies on all spheres of human life acquired significant proportions; it affected the educational system as well (Field, 2016). Education in the field of culture and art also develops on the basis of new technologies: electronic supplementary information, electronic libraries, virtual expositions, online exhibitions, auditions at music competitions, etc. The relevance of the study is related to the development of distance education (DL) in all countries, which resulted from the integration of countries into a single system of global education and adaptation to social realities; new distance technologies are thus becoming one of the leading modes of education that cover a significant and ever-increasing part of the world's population (Andreeva, 2016).

The humanitarization of vocational training of university students is characterized by a special emphasis in the modern educational processes, since humanitarization favors the development of general cultural competencies, forms a creative personality and promotes the preservation of the national socio-cultural identity. The increased need for distance education of university students is explained by one of the manifestations of the high socio-political dynamics of modern society with significant demographic, national and gender changes in the population, an increase in the leisure time of people, an increase in the general education of the population, the desire to realize oneself in the humanitarian sphere and art (Giedré, 2011; Kinast, 2005). In modern foreign social psychology and pedagogy, the need for the development of the creative and artistic abilities of an individual is viewed as an intrinsic motive of each person for learning the surrounding world, which persists throughout life, supported by the socio-economic dynamics of society (Vekker, 2009; Rathje, 2010). The humanitarization of education during distance learning allows establishing a connection with national values, as well as a connection between cutting-edge learning technologies and the formation of creative perception and understanding of world culture; it is designed to mutually enrich the interethnic culture, to form a culture of thinking and national identity. This process has a dialectical character - not only the humanitarization of education shapes the creative personality of a future

Submit Date: 10.07.2018, Acceptance Date: 22.08.2018, DOI NO: 10.7456/1080SSE/148

Research Article - This article was checked by Turnitin

Copyright (C) The Turkish Online Journal of Design, Art and Communication 
specialist, but also the socio-political and economic society influences the formation of a future specialist, who then influences politics, economics, culture. (Bolten, 2005; Heller, 2000). The analysis of foreign scientific literature and empirical data obtained by the authors in 2015-2017 in Moscow and St. Petersburg makes it possible to conclude that the distance education of university students should be based on interdisciplinary integrative education. International projects in intercultural communication aimed at developing intercultural skills and cooperation, in general, take a special place in the process of distance education using IT technologies (Rakitov, \& Anisimova, 2015; Dmitrieva, 2015); this approach is fully justified and can form the distance learning basis. The data obtained during the study led to the conclusion that the boundaries of the population involved in educational activities in the sphere of culture and art are expanding. In various European countries, Japan, the United States, Australia, hundreds of different training programs are now successfully performed, specially designed to train future specialists in the field of culture and art (Asmyatullin, 2016; Aidrus, 2015; Artamonova, 2011; Rakitov, \& Anisimova, 2015; Dmitrieva, 2015; Mukhanov, 2008; Bordovskaya, \& Rean, 2011; Yamaguchi, 2005).

The peculiarities of goal setting in the distance education system are revealed, which allows drawing a multidimensional scale of goals aimed at developing the competence of specialists by education. The main requirements for formulating goals and objectives are the following: instrumentality, diagnosticity, feasibility, attractiveness and context. Learning objectives should be integrated into the context of the social and professional spheres of activity of future specialists and correlated with the "summit" goal - the development of one's competence and creative abilities. In the process of isolating and analyzing the principles of developing potential of information and communication technologies in humanitarization of education that fosters the formation of personality of future specialists the following aspects were taken into account: the universality of creative and artistic thinking included in global creativity (Arnheim, 1994; Vekker, 2009; Fryer, 2012; Jin et al., 2016; Newton, \& Newton, 2014; Petre et al., 2016), dependence on the goal, active and operational nature, unity in the creative thinking of the sensible and conscious components (Fryer, \& Fryer-Bolingbroke, 2011).

In general, the information and communication technologies in the process of education humanitarization can be defined as a cultural and educational environment, as the most important factor in the formation of the creative abilities of future specialists, which determines their selfrealization in a multicultural space and promotes intercultural communication. The following most important characteristics of distance learning methods for the education can be considered: 1) the final goal-setting on the successful training and achievement of meaningful results during the activity and in socio-cultural environment; 2) the flexibility and dynamism of education, the humanitarization of education; 3) the ability to transform one's creative activity into socially significant activity in the context of globalization and integration.

\section{MATERIALS \& METHODS}

The analysis of theoretical and methodological sources in the field of pedagogy, psychology, philosophy, demography and statistics; systematic study of socio-cultural and cultural-pedagogical aspects of the formation and development of distance information and communication technologies in the process of humanitarization of education in the context of integration and globalization of the educational system; sociological methods (surveys, interviews, polls, analytical diagnosis); independent analytical expertise; experimental and practical verification of a model for creating an educational environment at educational institutions through distance learning (the processing of empirical materials, modeling, the study of regulatory documentation for distance education, the generalization of pedagogical experience); retrospective analysis of the author's own pedagogical experience in higher education institutions.

\section{Respondents:}

Students at institutions of additional education in Moscow, St. Petersburg, Krasnodar Krai, Anapa, Rostov Oblast, higher education institutions of Moscow, St. Petersburg, Krasnodar; the validity and suitability of the application of the methods and results of the study in specific conditions is obvious as the number of participants amounts to 2,450 students of all age groups, various areas of training in the field of culture and art, as well as 119 teachers, university professors and managers of distance education departments. 


\section{Stages:}

The first stage (2013-2014) is theoretical and methodological: the rationale for the development of a pedagogical model for the use of distance information and communication technologies in the process of humanitarization of education; selection, study and analysis of domestic and foreign scientific literature and statistical material on the issue; formation and discussion of the study methodology; generalization of pedagogical and management experience in the educational process.

The second stage (2015-2016) is experimental: it included the experimental substantiation of the study; processing and analysis of experimental data and educational models, psychological and pedagogical analysis of the learning process in forming the creative abilities; clarification of the developed methods of creative development, as well as the formation of socio-cultural and professional competencies; theoretical substantiation of distance information and communication technologies in the process of education humanitarization. At this stage, the developed pedagogical model was introduced, as well as the evaluation criteria for its implementation.

The third stage (2017-2018) is the completion of the analysis of scientific literature, summing up the main results of the experiment, systematization, interpretation and preparation of scientific conclusions based on the results.

In the study, the following distance learning (hereinafter - DL) criteria were singled out in the process of humanitarazing the vocational training of future specialists: the possibility of combining sociocultural, educational, ethical and personal principles; the goal is to achieve effective conditions for the creative development of each student using distance information and communication technologies, including professional pedagogical activity of teachers, based on the possibility of the distance information application, which allows students to most effectively realize their creative potential in a multicultural social environment; a dialogue of different cultures occurs, as well as the integration of humanitarian knowledge in the content of distance education; in the process of learning students form a holistic picture of the world on the basis of increasing motivation for constant selfdevelopment and self-education (Stukalova, Ilkevich, Ostanina, Moiseyev, Tomin, Fadeeva, 2017).

Distance information and communication technologies in the humanitarization of vocational training of future specialists realize the following basic functions: educational, creative, humanitarian; socially adaptive, allowing a student to take an active part in socialization; culturological which makes it possible to form an integral picture of the formation and development of culture; the implementation of an adequate evaluation of the influence of the holistic phenomenon of culture, its various types, branches, kinds and forms on the formation of social and spiritual qualities of an individual, social community, society as a whole; communicative; educational and disciplinary (Akishina, 2017).

The control analysis of the observational experiment (2017) showed that $84.5 \%$ of the students using distance information and communication technologies, who are engaged in distance learning for more than 3 years, have professional skills and abilities, are capable of applying the knowledge gained in practice in the process of humanitarization of vocational training, have a high level of readiness for intercultural dialogue, have tolerance and respect for another's culture, as well as the ability to preserve and increase their national culture, the desire for joint creative activity. Distance psychological and pedagogical observations, questioning, online interviews were conducted with the students (Likhanova, \& Nikitin, 2017).

\section{RESULTS}

As the study showed, distance education should be based on interdisciplinary training, the humanitarization of vocational training. It was confirmed that vocational education should be not only basic and practical but cultural in general, based on cognitive interests of students, developing their self-organization, aspiration to participate in research and creative projects and supporting the close interaction of all parties to the educational process (Figure 1).

In the course of the study, the authors tried to find out: students of what course of training in DL and age have positive perception of the humanitarization of vocational training? Various professions and a fairly wide representative sample of 17- to 45-year-olds were studied. It was found that the most 
important element of DL of future specialists is the humanitarization of the vocational training of students in the course of the well-coordinated activity of all parties to the educational process. In this case, the significance of belonging to a particular age group (the $\mathrm{Y}$ dependent variable), as well as the course of training (the $\mathrm{X}$ independent variable) do not have significant correlations (Table 1).

Table 1. Detection of Correlations in The Process of Assessment of The Vocational Training Humanitarianization

\begin{tabular}{|l|l|l|}
\hline № & $\begin{array}{l}\text { independent variable } \\
(X)\end{array}$ & $\begin{array}{l}\text { Dependent variable } \\
(Y)\end{array}$ \\
\hline 1 & Cultural Studies 1.25 & 2 \\
\hline 2 & Art History 1.12 & 2 \\
\hline 3 & Theory of Music 1.21 & 3 \\
\hline 4 & Literature Studies 1.21 & 2 \\
\hline 5 & Ethics \& Aesthetics & 3 \\
\hline 6 & Music 1.21 & 2 \\
\hline 7 & Vocals 1.11 & 3 \\
\hline 8 & Organists 1.1 & 2 \\
\hline 9 & Painting 1.32 & 3 \\
\hline 10 & Restoration 1.0 & 3 \\
\hline
\end{tabular}

The Spearman correlation coefficient $(\rho)=0.515$. The connection between the features under investigation is direct; the connection tightness (force) according to the Chaddock scale is noticeable. There are 8 degrees of freedom (f). The critical value of the Spearman test for a given number of degrees of freedom is 0.648. $\rho$.observe < $\rho$.crit; the dependence of the features is not statistically significant $(\mathrm{p}>0.05)$. 
The Turkish Online Journal of Design, Art and Communication - TOJDAC

ISSN: 2146-5193, September 2018 Special Edition, p.1080-1090

Goal: development of a distance learning (DL) model of future specialists in the field of culture and art on the basis of the humanitarization of the vocational training of future specialists

Objectives: 1 To theoretically justify the need for the humanitarization of vocational training in the process of distance learning. 2 To identify the specifics of increasing the level of development of humanitarian knowledge using up-to-date information and communication technologies in the learning process. 3. To test the model for implementing education through the DL system in the real practice of educational institutions. 4. To identify the criteria and levels of development of students in the humanities in DL. 5. To analyze the prospects for further development of up-to-date information and communication technologies in the process of humanitarization of vocational training of specialists

\begin{tabular}{|c|c|c|c|c|c|c|}
\hline 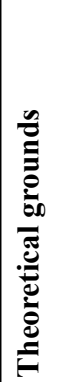 & 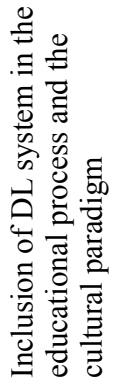 & 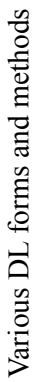 & 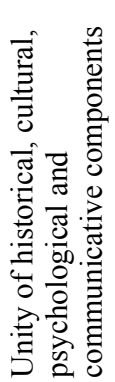 & 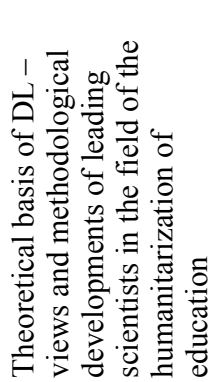 & 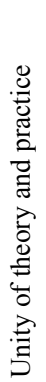 & 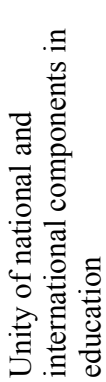 \\
\hline
\end{tabular}
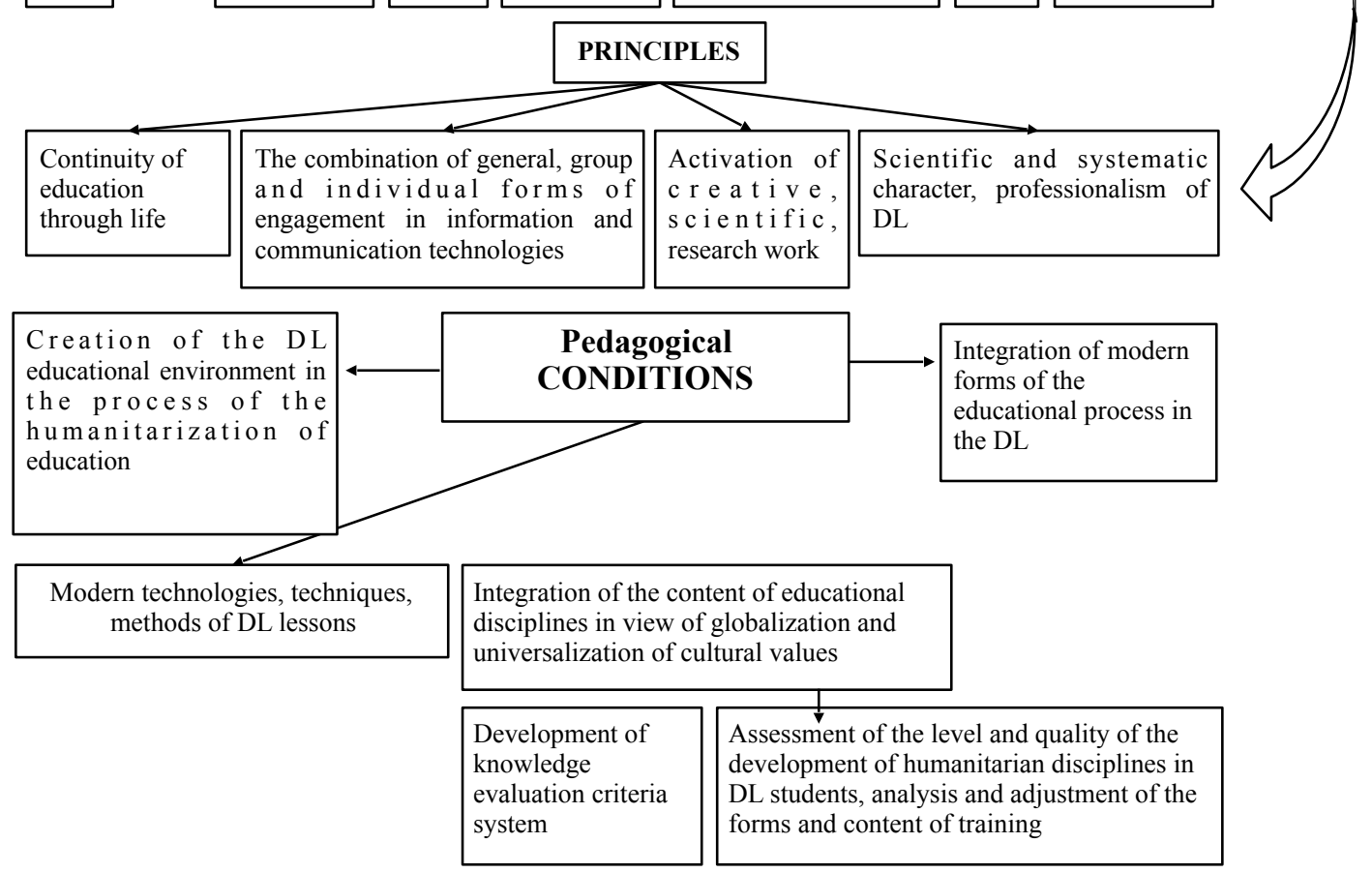

Criteria: theoretical and methodological mastering of the material; ability to assimilate, reproduce and interpret; objectivity of axiological and aesthetic evaluation; ability to draw reasoned logical conclusions; readiness for further selfeducation; respectful attitude towards the diversity of cultures and arts.

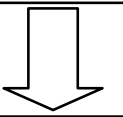

\section{Result: ability to carry out objective analysis, assimilation and scientific interpretation of contemporary culture and art}

Figure 1. Model of distance education of future specialists through the humanitarization of vocational training 
Conclusion: it was established that the focus on humanitarization is perceived positively by the students, regardless of their age and course of training. Consequently, in the process of DL, it is possible not only to transfer a certain set of knowledge, norms, values and competencies but also form value orientations as the basis for their further life, form aesthetic culture, tolerant attitude to national cultures and traditions. The formation of the culture of life self-determination is a central link (of DL) in the process of humanitarization; such a formation implies motivation to receive an education regardless of the age group of a student.

In another study, the objective was to establish a correlation between the work experience of specialists receiving education by DL in creative specialties and the indicators of successful (for the maximum grade in the assessment system) mastering of humanitarian disciplines that are aimed at forming an integral picture of the world, a worldview as the basis of the moral responsibility of a person to other people, society, culture, the formation of creative thinking (Krinitsyna et al., 2016) Table 2 .

Table 2. Detection of Correlations in The Process of Assessment of The Vocational Training Humanitarianization

\begin{tabular}{|l|l|}
\hline Work experience & Successful (maximum) mastering of humanitarian disciplines per 100 students \\
\hline Up to 1 year & 24 \\
\hline $1-2$ & 16 \\
\hline $3-4$ & 12 \\
\hline $5-6$ & 12 \\
\hline Over 7 years & 6 \\
\hline
\end{tabular}

The method of rank correlation is the most suitable method of analysis for the discussed issue since one of the indicators is presented in the form of open options: the work experience of up to 1 year, and work experience of over 7 years - Table 3 .

Table 3. Detection of Correlations in The Process of Assessment of The Vocational Training Humanitarianization

\begin{tabular}{|l|l|l|l|l|l|}
\hline $\begin{array}{l}\text { W o r } \quad \mathrm{k} \\
\text { experience }\end{array}$ & $\begin{array}{l}\text { M a x im um gra e for } \\
\text { mastering the discipline }\end{array}$ & No. & Ranks & $\begin{array}{l}\text { Difference of } \\
\text { ranks } \\
\text { D(x-y) }\end{array}$ & $\begin{array}{l}\text { Squared difference } \\
\text { of ranks }\end{array}$ \\
\hline Up to 1 year & 24 & 1 & 5 & -4 & 16 \\
\hline $1-2$ & 16 & 2 & 4 & -2 & 4 \\
\hline $3-4$ & 12 & 3 & 2.5 & +0.5 & 0.25 \\
\hline $5-6$ & 12 & 4 & 2.5 & +1.5 & 2.5 \\
\hline Over 7 & 6 & 5 & 1 & +4 & 16 \\
\hline
\end{tabular}

$\Sigma \mathrm{d} 2=38.5$. In the authors' calculation, the indicator of the successful (maximum) mastery of the humanities disciplines per 100 students is 12 ; this indicator is assessed twice and is assigned ranks 2 and 3; find the arithmetic mean of these ranks $(2+3) / 2=2.5$. Thus, the Spearman coefficient is -0.92 .

$$
\rho \_x y=1-(6 \times 38.5) / 5\left(5^{\wedge} 2-1\right)=1-325 / 5(25-1)=1-325 / 120=1-1.92=-0.92
$$

A negative value indicates the presence of a feedback between the features and allows stating that the little work experience is accompanied by a large number of students who successfully mastered the 
disciplines of the humanitarian course, and vice versa, the students who already have a certain experience, master the humanitarian disciplines less successfully because they are more oriented to special profile subjects, provided by the educational course; during the additional survey, it was revealed that in the process of DL, positive constructive relations in the learning process and a transparent methodology for assessing knowledge seem to be more significant (Romanov, 2014).

The analysis of the scientific literature (Stukalova, 2017; Torshilova, \& Polosukhina, 2016) and the data obtained by the authors make it possible to draw a number of conclusions that in the process of humanitarization of specialists within DL, it is important to take into account a number of the following methodologically significant aspects:

- Creation of a scientifically grounded system of interaction of special (practice-oriented) disciplines of the specialty and disciplines of the humanitarian course in DL;

- Development of a comprehensive integrative approach to the educational process, connecting the emergence of new directions of education in the context of globalization, and new theories and paradigms that actualize the humanitarization of future specialists;

- In addition, in the process of humanitarization of vocational training using up-to-date DL technologies, it is necessary to consider a number of features of implementing DL in the system of Russian higher education: the integration of Russian education into the international educational environment, the government demand for the relevant specialists, the dynamics of the labor market demand depending on the region, the prestige of a profession and a number of other criteria, as well as the unification of the educational platform of the CIS countries (Alekseeva, 2014; Alekseeva, 2015a; Alekseeva, 2015b; Akishina, 2017), and others.

- The practical work experience, the possibility of implementing the education for career development, age, social status, marital status.

- The focus on the formation of a person-oriented program for each student should be one of the motivating factors for obtaining DL when considering DL as part of continuing education throughout life.

In the course of DL, the humanitarization of vocational training is provided by an integrative, interdependent system that creates conditions for mastering the global and national culture and spiritual values of art (Alekseeva, \& Savenkova, 2017). Achieving these goals is possible only under the condition of a qualitative change in the content of DL and adaptation of methods, approaches to teaching, depending on the course of training, and on a student's personality. In addition to the humanitarization of vocational training, a trainee forms the core competencies, knowledge and skills that meet the current needs of society and the state; DL determines the significance of the development of a positive worldview, forms a stable view on the possibility of a creative attitude towards the mastery of reality and adaptation in it; provides support for creative thinking; provides an opportunity to become familiar with the achievements of world culture; in the process of using modern technologies, develops positive communicative and organizational abilities necessary for future career (Stukalova, 2017).

In general, all parties to the educational process, taking part in various events held in the framework of DL, are confident in the possibility of obtaining high-quality vocational education on the basis of humanitarization.

During the study, distance interviews were conducted: an interview-portrait (disclosure of a personality); a group interview-discussion in the format of webinar (identification of possible points of view); a questionnaire (fixing the opinions of different people, but only on one issue). As a result, the authors found that there is a high level of motivation for DL as a form of education $(85.9 \%)$, awareness of the need for the humanitarization of knowledge (78.5\%), total readiness for further education at the next stage of education (master's, post-graduate, 68\%); the students showed high optimism and confidence in the opportunity to realize the acquired knowledge (88.4\%), since they spend their free time actively participating in collective activities, in various creative teams, and so on. 
At the same time, $92.3 \%$ of the students, obtaining bachelor's and master's degrees, are characterized by an assessment of the surrounding people, based primarily on their personal qualities, abilities, and not on national, religious or gender peculiarities. At the beginning of the classes, the percentage was significantly different and the assessment was given not based on personal qualities of an individual, but on the basis of belonging to one or another social group, which demonstrated stereotypes and subjective opinion. It is noteworthy that the prospects for solving international, social, humanitarian, gender problems rely primarily on resources of culture and education, the art of joint creativity, and not on government control and political parties. This is due to the fact that the experience of DL using the achievements of world culture and art, international communication, the organization of discussion panels with the use of information and communication technologies proves the effectiveness of such interaction in the process of humanitarization of education. Joint training in the process of DL, the discovery of new cultural values of other peoples, the inclusion of another culture in real life unite and motivate students for an in-depth study of the disciplines of the humanitarian unit.

In the course of the study, the following conclusions were drawn: the main components that should be taken into account when setting up the environment of DL are the creation of an education operating shell that would ensure effective pedagogical support in the learning process.

The basic principles of the DL organization in the process of humanitarization of vocational training of specialists were revealed: the problem-thematic structuring of education; application of information and communication technologies (creation of an interactive space for students, design technologies, organization of independent research creative activity of students, business games, game modeling, etc.); correlation of culture and personality in the cultural and educational environment; integration of forms and methods of self-development of the individual with educational technologies (Savenkova, 2014).

Facultative principles of the DL institution in the process of humanitarization of vocational training of specialists: a combination of compulsory course subjects, elective disciplines; a combination in the process of national and international education; overcoming stereotypes, dogmas, and subjective assessments of the objective picture of the world; formation of the educational curriculum on the basis of world achievements in the field of culture and art; taking into account regional, religious, national, geographical peculiarities of students; formation of interest in further education throughout life; creation of conditions for self-realization through the assimilation of the world cultural heritage (Akishina, 2017; Alekseeva et al., 2018).

The special principles of the humanitarization of vocational training are the following: the construction of the content of the educational process, taking into account the differentiated environment of students studying the humanitarian disciplines; politicization of the DL process; the formation of competencies from the level of knowledge to the level of mastering of humanistic values; the systematic nature of humanitarization: the logical aligned courses, the categorical and conceptual continuity of the sources of education; the analysis of original literature, primary sources; emphasis on the further creative development of acquired knowledge.

The leading components of the educational process in the process of humanitarization that create the necessary and mandatory conditions for obtaining quality education, creative self-realization, guaranteed realization of the potential after graduation are defined: the development of a sense of responsibility and importance of the future career; formation of the sustainable professional intercultural, interethnic dialogue; development of readiness to preserve cultural and historical values; preparation for further education at all levels of education and at various educational platforms, including advanced training.

\section{DISCUSSION}

The peculiarity of the humanitarization of vocational training of future specialists with the use of information and communication technologies in the DL process is reflected in the results of the activities of all participants of the educational process; in the appropriate psychological, methodical, technical, and informational training of the participants of DL for the most effective assimilation of educational standards, the formation and development of competent, creative, communicative abilities of future specialists in the field of culture and art; in the ability to effectively collaborate with 
moderators, teachers, other students, the formation of a creative, productive, interactive atmosphere of the DL.

In this regard, a student's personality is the main value of the humanitarization of vocational training in the DL process, as well as the motivation for comprehensive constructive interaction, the formation and development of creative abilities. The DL process is conditioned by its methodological, technical support; fundamental theoretical, and at the same time practical orientation; creative humanistic orientation, general cultural and professional completeness.

In the process of humanitarization of vocational training using the information and communication technologies of distance learning, the participants of the educational process are constantly in a situation of intercultural dialogue, which is an important factor for the development of creative abilities, the formation of professional creative competencies, the preservation of cultural identity and adaptation to the diversity of forms and content of culture.

\section{CONCLUSION}

The generalization of the results of the study made it possible to determine the importance of the humanitarization of vocational training in DL for a more effective impact on the development of a student's personality, necessary for the full disclosure of creativity in the context of globalization of the world and the establishment of intercultural dialogue. DL allows creating such an environment in the process of educational, creative, scientific activity of students most effectively. It is possible to substantiate the factors influencing the educational environment of DL created in the team, as well as the formation of the personality of a future specialist:

- the flexibility of the system of the DL pedagogical support, based on personal-oriented learning (Akishina, 2017; Alekseeva, 2016; Stukalova, 2017; Medkova, 2017) and qualified pedagogical interaction (Kashekova, 2017, Belov, 2017; Komandyshko, 2016; Komandyshko, \& Semenova, 2017), when the educational curriculum, the logic of the course, a set of humanitarian disciplines, the teaching staff form the priority of the development of a person as an active subject of culture and art;

- the establishment of such relations in the process of humanitarization of DL, where students, regardless of their gender, age, religion, nationality, have an opportunity for full personal, professional, creative development and realization of their potential on the basis of diversity and unity of the world, the place and unique role of each person in preservation of the cultural values of his or her people and peoples of the world.

\section{ACKNOLEDGMENT}

The results of the research were obtained within the framework of the state task of the Ministry of Education and Science of Russia (27.7394.2017/8.9).

Ekaterina M. Akishina, Candidate of History of Art, Director of the Federal State Budget Scientific Institution "Institute of Art Education and Cultural Studies of the Russian Academy of Education" for supporting and promoting conceptual ideas for the modernization of the content and technologies of teaching Art in the Russian Federation (2016-2017).

Larisa E. Slutskaya, Doctor of Pedagogical Science, Professor, Provost of Moscow State Tchaikovsky Conservatory for the materials of pedagogical and experimental activities in achieving the planned results and assessing the quality of music education of students (2016-2018).

\section{REFERENCES}

Aidrus, I.A. (2015). Sistemy upravleniya obucheniem kak faktor povysheniya konkurentosposobnosti rossiiskikh vuzov [Education Management Systems as a Factor to Increase the Competitiveness of Russian Universities]. Alma mater (Vestnik vysshei shkoly), 6, 63-68.

Akishina, E.M. (2017). Features of Mastering the Modern Musical Continuum by the Youth Audience in Russia. Man in India, 97(22), 43-52.

Akishina, E.M., Krasilnikov, I.M., \& Medkova, E.S. (2017). Interpretation of Religious Plots in the 20th Century Russian Music and Visual Arts. European Journal of Science and Theology, 13(3), 195-203. 
The Turkish Online Journal of Design, Art and Communication - TOJDAC ISSN: 2146-5193, September 2018 Special Edition, p.1080-1090

Alekseeva, L.L. (2014). O sostoyanii i perspektivakh razvitiya. Observatorii khudozhestvennogo obrazovaniya gosudarstv-uchastnikov SNG [On the State and Prospects of Development. Observatory of Art Education of the CIS Member States]. Pedagogika iskusstva, 3. Retrieved from http://www.arteducation.ru/sites/default/files/journal pdf/alekseeva 1.pdf. July 22, 2018

Alekseeva, L.L. (2015a). Issledovaniya v oblasti khudozhestvennogo obrazovaniya $v$ kontekste reformirovaniya otechestvennoi nauki [Study in the Field of Art Education in the Context of Reforming the National Science]. Pedagogika iskusstva, 1. Retrieved from http://www.art-education.ru/sites/ default/files/journal pdf/alexeeva.pdfJuly 22, 2018

Alekseeva, L.L. (2015b). Tvorcheskoe razvitie uchashcheisya molodezhi: $k$ probleme opytnoeksperimentalnogo issledovaniya [Creative Development of Young Students: to the Issue of Experimental Study]. Gumanitarnoe prostranstvo, 4(2).

Alekseeva, L.L., \& Savenkova, L.G. (2017). Art Classes at School and Intellectual and Creative Child Development. Espacios, 38(56), 3.

Alekseeva, L.L., \& Yaroshenko, N.N. (2015). Traditsii - novatsii - perspektivy: $k$ 85-letiyu Moskovskogo gosudarstvennogo Instituta kultury $i$ Instituta khudozhestvennogo obrazovaniya Rossiiskoi akademii obrazovaniya [Traditions - Innovations - Prospects: to the 85th Anniversary of the Moscow State Institute of Culture and the Institute of Art Education of the Russian Academy of Education]. Vestnik Moskovskogo gosudarstvennogo universiteta kultury i iskusstv, 2(64).

Alekseeva, L.L., Sorokoumova, E.A., Vakhrusheva, L.N., Litvinov, A.V., Popovitskaya, N.V., \& Filipenkova, O.G. (2018). Pedagogical Opportunities for Student Communicative Culture Development. XLinquae, 1, 203-217. Retrieved from http://www.xlinguae.eu/issue n 1 2018.html July 22, 2018

Andreeva, L.Yu. (2016). Marketingovye instrumenty globalnoi innovatsionnoi giperkonkurentsii [Marketing Tools of Global Innovative Hypercompetition]. Moscow: Vuzovskaya kniga, 328.

Artamonova, Yu.D. (2011). Sovmestnye obrazovatelnye programmy vuzov: sostoyanie, problemy, perspektivy [Joint Educational Curriculum of Universities: Status, Issues, Prospects]. Moscow: KDU, 56.

Asmyatullin, R.R. (2016). Rossiiskie universitety na mirovom rynke obrazovatelnykh uslug: taktika $i$ strategiya [Russian Universities in the World Market of Educational Services: Tactics and Strategy]. Vestnik Rossiiskogo universiteta druzhby narodov. Seriya "Ekonomika", 2, 99-107.

Bolten, J. (2005). Interkulturelle Personalentwicklungsmaßnahmen: Training, Coaching und Mediation. Stahl, Mayrhofer, Kühlmann. Innovative Ansätze im Personalmanagement. München, 307-324.

Bordovskaya, N., \& Rean, A. (2008). Pedagogika. Gl. IV: Obrazovanie v mire: istoriya i sovremennost [Pedagogy. Ch. IV: Education in the World: History and Modernity]. Retrieved from https:/l www.gumer.info/ July 22, 2018

Field, J. (2016). Lifelong Learning and the New Educational Order. Sterling (USA): Trentham Books, 37.

Fryer, M. (2012). Making Sense of Creativity from a Psychological Perspective. Creativity and Human Development, 5, 1-8. Retrieved from https://creativityjournal.net/component/k2/item/81-making-senseof-creativity-from-a-psy-chological-perspective\#.Wd6dF1uOPIU

Giedré, P. (2011). Rollenspiel als Ausgangspunkt für interkulturelles Lernen im Fachbereich Berufsdeutsch. Kalbqstudijos, 18, 90-96.

Heller, B. (2000). Angewandte interkulturelle Kommunikation im Hochschulbereich "Comparative cultural studies in different media" am Beispiel eines projektorientierten Seminars für internationale Studierende der Wirtschafts- und Ingenieurwissenschaften. Hamburg: Dr. Kovac, 240.

Jin, X., Wang, Y. \& Dong, H. (2016). The Relationship between Self-Construal and Creativity Regulatory Focus as Moderator. Personality and Individual Differences, 99, 282-288. DOI:10.1016/ j.paid.2016.03.044

Kashekova, I., \& Kolosova, S. (2016). In Continuation of the Discussion about Ratio Science and Human Knowledge in the Education of Modern Man. International Journal of Environmental and Science Education, 11(18), 12593-12603.

Kinast, E.U. (2005). Interkulturelles Training. In Handbuch Interkulturelle Kommunikation und Kooperation. Band 1: Grundlagen und Praxisfelder. Göttingen: Vandenhoeck \& Ruprecht. 181-203.

Komandyshko, E.F., \& Semenova, E.A. (2017). Educational Tourism: Adoption of Management Technologies in the Activity of Universities. Journal of Environmental Management and Tourism, 8, 6(22), 1183-1188.

Submit Date: 10.07.2018, Acceptance Date: 22.08.2018, DOI NO: 10.7456/1080SSE/148

Research Article - This article was checked by Turnitin

Copyright (C) The Turkish Online Journal of Design, Art and Communication 
Komandyshko, E.Ph. (2016). Arts Management Innovative Technologies in the Creative Development of Youth. International Review of Management and Marketing, 6(S3), 234-238. Retrieved from http:// econjournals.com/July 22, 2018

Krinitsyna, A., Nikitin, O., \& Boyakova, E. (2016). Characteristics of the Creative Development Technologies Applying during the Work with Students. International Journal of Environmental \& Science Education, 11(18), 11709-11720. Retrieved from file:///C:/Users/User/Downloads/ IJESE 1632 article 583bf72ee3e4e.pdf July 22, 2018

Likhanova, E.N., \& Nikitin, O.D. (2017). Psychological-Pedagogical Potential of Media Culture: Principles and Prospects for the Development of Cinema Pedagogy. Rupkatha Journal on Interdisciplinary Studies in Humanities, 9(3), 36-51.

Medkova, E.S. (2017). Teaching Traditional Folk Culture at Modern Russian General Education School. Revista Espacios, 38(56), 30.

Mukhanov, V. (2008). Obrazovanie v Yaponii [Education in Japan]. Retrieved from http:// www.edunews.ru/ July 22, 2018

Newton, L., \& Newton, D. (2014). Creativity in 21st-Century Education. Prospects, 44(4), 575-589. DOI: $10.1007 / s 11125-014-9322-1$

Petre, V.G., Tanggaard, L.P. \& Wegener, C. (2016). Creativity - A New Vocabulary. Palgrave Macmillan, 36-42. doi: 10.1057/9781137511805

Rathje, S. (2010). Training/Lerntraining. In Wie lehrt man interkulturelle Kompetenz? Theorien, Methoden und Praxis in der Hochschulausbildung. Ein Handbuch. Bielefeld, 215-240.

Romanov, E.V. (2014). Protivorechiya kak istochnik innovatsionnogo razvitiya sistemy vysshego professionalnogo obrazovaniya [Contradictions as a Source of Innovative Development of the System of Higher Professional Education]. Almamater (Vestnik vysshei shkoly), 5, 9-13.

Savenkova, L.G. (2014). Vospitanie cheloveka v prostranstve mira i kultury: integratsiya v pedagogike iskusstva: monografiya [Education of Man in the Space of the World and Culture: Integration in the Pedagogy of Art: A Monograph]. Moscow: MAGMU - Russian Presidential Academy of National Economy and Public Administration.

Stukalova, O.V. (2017). Pedagogicheskie napravleniya obespecheniya informatsionnokommunikativnoi bezopasnosti $v$ sovremennoi obrazovatelnoi srede [Pedagogical Directions of Providing Information and Communication Security in the Modern Educational Environment]. Kazanskii pedagogicheskii zhurnal, 5(124), 45-49.

Stukalova, O.V. (2017). The System of Cultural and Creative Development of Students in the Educational Environment of Higher Education Institutions in the Sphere of Culture and Art. Espasios, 38(56), 33.

Vekker, L.M. (2009). Psikhika i realnost. Edinaya teoriya psikhicheskikh protsessov [Mentality and a Reality: The Uniform Theory of Mental Processes]. Moscow, 685.

Yamaguchi, K. (2005). Development of Special Needs Education in Japan and Some Current Problems. In Inclusive and Supportive Education Congress International Special Education Conference Inclusion: Celebrating Diversity? 1st-4th August 2005. Glasgow, Scotland. 